\title{
INFLUENCE OF MEDIUM CHAIN FATTY ACIDS ON SOME BOTRYTISED WINE-RELATED YEAST SPECIES AND ON SPONTANEOUS REFERMENTATION OF TOKAJ ESSENCE
}

\author{
B. OlÁhné Horváth*, E. FAZeKas, N. Kellner and I. Magyar \\ Department of Oenology, Faculty of Horticulture, Szent István University, H-1118 Budapest, Ménesi út 45. \\ Hungary
}

(Received: 23 March 2020; accepted: 13 May 2020)

\begin{abstract}
Medium chain fatty acids are candidates of partial sulphur dioxide replacement in wine, as a solution to the growing consumer concerns about chemical additives. In botrytised sweet wine specialties, large amount of sulphur dioxide addition is one of the effective practices to stop alcoholic fermentation. Increasing medium chain fatty acid levels up to $80 \mathrm{mg} \mathrm{l}^{-1}$ was tested as a sole inhibitor on solid agar surface. $S$. bacillaris seemed to be the most sensitive, $S$. cerevsisiae and S. bayanus were more tolerant, while Z. bailii showed the highest tolerance. Then, increasing medium chain fatty acid levels up to $40 \mathrm{mg} \mathrm{l}^{-1}$ combined with $100 \mathrm{mg} \mathrm{l}^{-1}$ sulphur dioxide was introduced into a Tokaj Essence under refermentation. After 56 days, the highest dosage had pronounced effect on the yeast population, but the refermentation was not inhibited completely. Medium chain fatty acids have varying inhibitory effect on botrytised wine-related yeasts, moreover, it could be used effectively in media with high ethanol content, unlike Tokaj Essence.

Keywords: medium chain fatty acids, Starmerella bacillaris, Zygosaccharomyces bailii, Saccharomyces cerevisiae, Saccharomyces uvarum
\end{abstract}

Nowadays, consumers are particularly concerned about health aspects, connected with sulphite toxicity in wine, therefore, the current general tendency is to reduce the use of sulphite in winemaking. Sulphur dioxide is the most frequently used chemical additive in winemaking, employed for multiple benefits as antiseptic, antioxidant, colour-, fragrance-, and taste protector (SANTOS et al., 2012). Based on current knowledge, none of the studied alternatives can totally replace $\mathrm{SO}_{2}$, which remains a useful, sometimes indispensable agent.

In Tokaj botrytised wine specialties, it is a widespread practice to stop alcoholic fermentation and save the residual sugars with a considerable $\mathrm{SO}_{2}$ addition in combination with cooling, racking, and microfiltration (MAGYAR, 2011). In some cases, it is a challenge to meet the upper limit of total $\mathrm{SO}_{2}$ concentration set by EU Commission legislation 607/2009/ $\mathrm{EC}$ (EC, 2009). Consequently, any effective $\mathrm{SO}_{2}$ replacement could facilitate botrytised winemaking.

Recent candidates for partial substitution of $\mathrm{SO}_{2}$ in wine are medium chain fatty acids (MCFA). MCFA and their esters are common yeast secondary metabolites usually produced in small quantities (BALMASEDA et al., 2018). Earlier studies revealed that artificially added MCFA could be used to stop an alcoholic fermentation carried out by S. cerevisiae (BABIKOVA et al., 2012), inhibit refermentation (BARON, 2014), and consequently decrease the necessary $\mathrm{SO}_{2}$ addition. MCFA application in wines is studied only by a few (e.g. BABIKOVA et al., 2012;

\footnotetext{
* To whom correspondence should be addressed

Phone: +36-1-3057347; e-mail: olahne.horvath.borbala@kertk.szie.hu
} 
BARON et al., 2017) in normal winemaking environments. However, the inhibitory effect might be significantly different for various yeast species and in special winemaking environments, like botrytised winemaking.

In case of botrytised wine fermentation, the original yeast biota of the grape berry is altered considerably (reviewed by e.g. SIPICZKI, 2019), the harsh fermentation conditions are tolerable only for the well-adapted species. Beside others, Saccharomyces cerevisiae has great importance, Saccharomyces bayanus is also well presented (MASNEUF-POMAREDE et al., 2010). Starmerella bacillaris (syn. Candida zemplinina) was originally described in Tokaj wine region and connected to botrytised, sweet wine fermentation (SIPICZKI, 2003). Due to the significant amount of remaining sugars, refermentation of these wine specialties by the tolerant spoilage yeast Zygosaccharomyces bailii is a major threat (ALONso et al., 2015).

In this study, first we focused on the characterisation of the general tolerance of $S$. cerevisiae, S. bayanus, S. bacillaris, and Z. bailii against MCFA as a sole additive in the medium. Furthermore, various MCFA concentrations were tested in combination with $\mathrm{SO}_{2}$ to inhibit spontaneous refermentation in a Tokaj Essence.

\section{Materials and methods}

\subsection{Tolerance test}

Yeast strains: Yeast strains are shown in Table 1. Natural isolates were previously identified by their rDNA and ITS regions (based on the methods of ZотT and co-workers, 2010) except $Z$. bailii strains, which were formerly identified by classical methods, upon characteristic sporulation and physiological traits. Inoculum was prepared in YEPD broth $\left(20 \mathrm{~g}^{-1}\right.$ glucose, $10 \mathrm{~g} \mathrm{l}^{-1}$ peptone, and $10 \mathrm{~g} \mathrm{l}^{-1}$ yeast extract), incubated $\left(25^{\circ} \mathrm{C} / 48 \mathrm{~h}\right)$ without agitation.

Culture media: For preculturing the strains, fermentation was performed in a model medium ( $40 \mathrm{~g} \mathrm{l}^{-1}$ glucose, $0.75 \mathrm{~g} \mathrm{l}^{-1} \mathrm{MgSO}_{4} \times 7 \mathrm{H}_{2} \mathrm{O}, 1.0 \mathrm{~g} \mathrm{l}^{-1} \mathrm{KHPO}_{4}, 5.0 \mathrm{~g} \mathrm{l}^{-1}$ peptone, 3.0 $\mathrm{g}^{-1}$ yeast extract, and $3 \mathrm{~g} \mathrm{l}^{-1}$ DL-malic acid, $\mathrm{pH}=3.5$ ). Agar plates used for drop test had a composition identical with the model medium except for $5 \mathrm{v} / \mathrm{v} \%$ ethanol, $15 \mathrm{~g} \mathrm{l}^{-1}$ agar-agar, and increasing MCFA concentrations.

Fermentation conditions: Fermentation (preculturing) was carried out under semianaerobic condition at $20^{\circ} \mathrm{C}$, in test tubes containing $5 \mathrm{ml}$ aliquots of model media, without shaking. Tubes were inoculated to a level of $1 \times 10^{6} \mathrm{cell} \mathrm{m}^{-1}$ with 48 -hour-old yeast cultures grown in YEPD broth. Cell concentration was measured by Bürker chamber cell counting after $72 \mathrm{~h}$ of fermentation.

Drop test: After 72-hour fermentation without preservative, the inhibitory effect of MCFA was tested on solid agar surface. The test was carried out with $5 \mu \mathrm{l}$ of serial dilutions from the cultures $\left(10^{-1}, 10^{-3}, 10^{-5}\right)$, in triplicate, according to PEREZ-ToRRADO and co-workers' (2016) modified method. Into the agar $0,10,20,40$, and $80 \mathrm{mg}^{-1}$ MCFA mixture was introduced. Upon the results of BARON (2014), the MCFA mixture contained $\mathrm{C}_{8}: \mathrm{C}_{10}: \mathrm{C}_{12}$ in 2:7:1 ratio, solved in $70 \mathrm{v} / \mathrm{v} \%$ ethanol. After 7 days of incubation at $20^{\circ} \mathrm{C}$, drop test images were recorded in a fix vision system with a Sony Exmor RSIMX315 camera (Sony Corp., Minato, Japan). Growth area analysis with ImageJ software (SCHNEIDER et al., 2012) was used to assess the capability of the strains to grow under various MCFA conditions. Growth values given as percentage are raw colony area-means of triplicate drop-tests, normalised with the control growth of each strain. Data were evaluated with ANOVA after checking the assumptions, using IBM SPSS 23.0. Armonk, NY, USA.

Acta Alimentaria 49, 2020 
Table 1. Yeast strains used in this study

\begin{tabular}{|c|c|c|c|}
\hline Species & Strain & Source & Origin \\
\hline \multirow{5}{*}{$\begin{array}{l}\text { Saccharomyces } \\
\text { cerevisiae }\end{array}$} & RA100 & DO-SZIU & Tokaj Aszú, Tokaj wine region, HU \\
\hline & PM321 & DO-SZIU & Tokaj Aszú, Tokaj wine region, HU \\
\hline & S701 & DO-SZIU & Somló wine region, $\mathrm{HU}$ \\
\hline & Uvaferm $\mathrm{PM}^{\circledR}$ & Lallemand Inc. & commercial starter culture, selected in FR \\
\hline & Uvaferm $228^{\circledR}$ & Lallemand Inc. & commercial starter culture, selected in DE \\
\hline \multirow[t]{5}{*}{ Saccharomyces uvarum } & $\mathrm{CBS} 395^{\mathrm{T}}$ & NCAIM & black current juice, $\mathrm{NL}$ \\
\hline & TKH1 & DO-SZIU & Tokaj Aszú, Tokaj wine region, HU \\
\hline & SB42 & DO-SZIU & Tokaj Aszú, Tokaj wine region, HU \\
\hline & E105 & DO-SZIU & Etyek-Buda wine region, $\mathrm{HU}$ \\
\hline & $\mathrm{S} 103$ & DO-SZIU & Somló wine region, HU \\
\hline \multirow[t]{5}{*}{ Starmerella bacillaris } & $\mathrm{Y} 1667^{\mathrm{T}}$ & NCAIM & Tokaj Aszú, Tokaj wine region, HU \\
\hline & Y1756 & NCAIM & Aszú berry, Tokaj wine region, HU \\
\hline & MLO & DO-SZIU & Etyek-Buda wine region, $\mathrm{HU}$ \\
\hline & SJ1 & DO-SZIU & Aszú berry, Tokaj wine region, HU \\
\hline & $\mathrm{R} 1$ & DO-SZIU & Aszú berry, Tokaj wine region, HU \\
\hline \multirow{5}{*}{$\begin{array}{l}\text { Zygosaccharomyces } \\
\text { bailii }\end{array}$} & Y954 ${ }^{\mathrm{T}}$ & NCAIM & sorghum brandy mash, JP \\
\hline & Z6 & DO-SZIU & $\mathrm{SO}_{2}$ preserved must, $\mathrm{HU}$ \\
\hline & $\mathrm{Z} 22$ & DO-SZIU & Badacsony wine region, $\mathrm{HU}$ \\
\hline & PM614 & DO-SZIU & Tokaj Aszú, Tokaj wine region, HU \\
\hline & DS3 & DO-SZIU & Mátra wine region, $\mathrm{HU}$ \\
\hline
\end{tabular}

DO-SZIU: Department of Oenology, Szent István University; NCAIM: National Collection of Agricultural and Industrial Microorganisms; FR=France, $\mathrm{DE}=$ Germany; $\mathrm{NL}=$ the Netherlands; HU=Hungary; JP=Japan

\subsection{Inhibition of refermentation in Tokaj Essence by MCFA}

Culture media: A Tokaj Essence from Vintage 2005 was bottle aged by the producer at $12{ }^{\circ} \mathrm{C}$ in cellar conditions, then re-bottled in 2018 into Tokaj-shape 0.331 bottles. After two weeks of bottling the Essence was sent to our laboratory in a spontaneous refermentation state with $1.86 \times 10^{5} \mathrm{CFU} \mathrm{m} l^{-1}$ initial cell concentration. Total yeast count was determined by culturing on DRBC agar (Sigma Aldrich), and the population was found heterogeneous upon colony and microscopic morphology (no further identification was performed). Basic parameters of the Tokaj Essence were determined according to the official OIV methods: $0 / 38 \mathrm{mg} \mathrm{l}^{-1}$ free/ total $\mathrm{SO}_{2}$ (OIV-MA-AS323-04B), $54.19{ }^{\circ}$ Brix total soluble solids (OIV-MA-AS2-02), 2.32 $\mathrm{v} / \mathrm{v} \%$ ethanol (OIV-MA-AS312-01A).

Refermentation conditions: To stop the spoilage, $0,10,20$, and $40 \mathrm{mg}^{1^{-1}}$ of MCFA mixture was applied to $150 \mathrm{ml}$ of Tokaj Essence in $200 \mathrm{ml}$ flasks, in duplicates, incubated at $15^{\circ} \mathrm{C}$. After $24 \mathrm{~h}$ of the MCFA dosage $100 \mathrm{mg} \mathrm{l}^{-1} \mathrm{SO}_{2}$ was added to each of these treatments, (except for an absolute control, where no $\mathrm{SO}_{2}$ and no MCFA were used) according to the recommendation of an earlier study (BARON, 2014). Composition of the MCFA mixture was identical with the above described (see drop test section). Population dynamic changes of the 
MCFA-treated Tokaj Essence was followed with traditional plating of serial dilutions on DRBC agar surface, sampling at day $0,1,2,7,14,21,28$, and 56.

All chemicals were purchased from Sigma-Aldrich Chemie Gmbh (Munich, Germany).

\section{Results and discussion}

\subsection{Tolerance test}

Four botrytised wine-related yeast species were evaluated in terms of their tolerance in growth towards increasing amounts of MCFA. Considering the suggested practical application of MCFA, that is to stop fermentation (BARON, 2017), the conditions of the test included a small amount (5\%) of ethanol present in the medium. All species under study showed some intraspecific variation between $5.8 \%$ and $25.6 \%$, without correlation among better MCFA tolerance, better fermentation ability (e.g. MAGYAR \& TóTH, 2011), and geographical origin (Table 1).

Due to the increasing MCFA levels, considerable differences were detected among the investigated species in their tolerance (Fig. 1). At $10 \mathrm{mg} \mathrm{l}^{-1}$ MCFA, all S. bacillaris strains were slightly inhibited, while the other three species were not influenced significantly (Fig. 2). In earlier studies, this MCFA level seemed to be effective in combination with $\mathrm{SO}_{2}(100$ $\mathrm{mg} \mathrm{^{-1 }}$ total) and a higher concentration of ethanol $(12 \mathrm{v} / \mathrm{v} \%)$ in fermenting wine (BARON et al., 2017). From our results it could be seen that the MCFA mixture without $\mathrm{SO}_{2}$ and with the presence of only $5 \mathrm{v} / \mathrm{v} \%$ ethanol cannot inhibit the growth of the investigated strains at this low concentration.

A
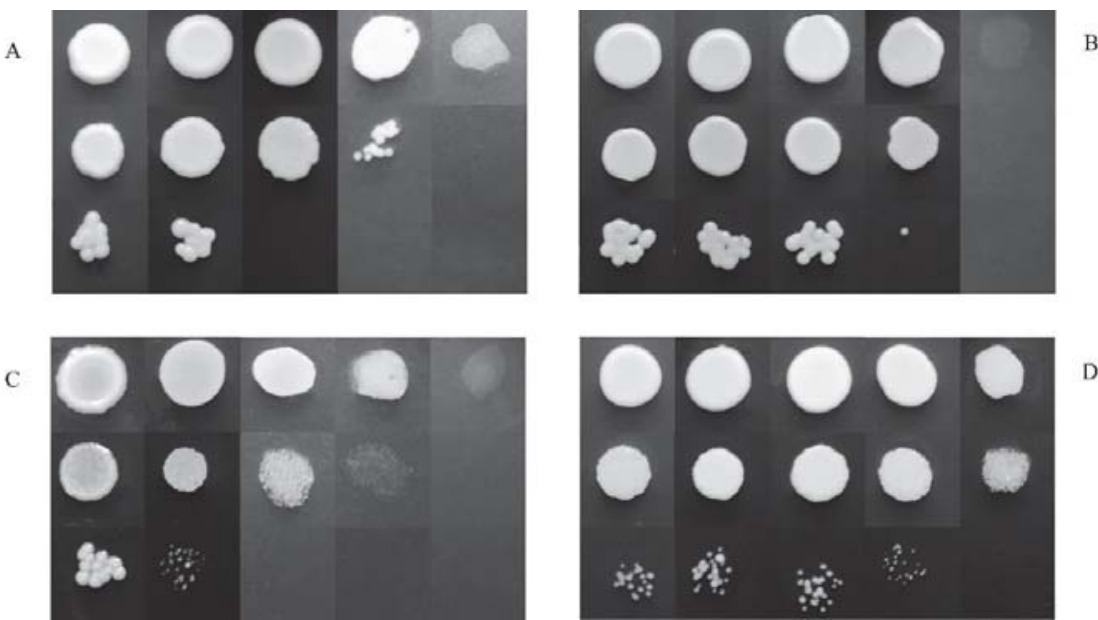

Fig. 1. Tolerance comparison of the investigated species towards MCFA. A: S. cerevisiae UVAFERM PM, B: S. uvarum TKH1, C: S. bacillaris Y1756, D: Z. bailii Z6. Vertical bands show serial dilutions of one culture $\left(10^{-1}, 10^{-3}, 10^{-5}\right)$ plated on model media completed with increasing MCFA levels. Different bands from left to right display 0-10-20-40-80 $\mathrm{mg}^{-1}$ MCFA. A representative image of the strains from the biological triplicates is presented 
At 20 and $40 \mathrm{mg} \mathrm{l}^{-1}$ MCFA, S. bacillaris strains were further inhibited. S. cerevisiae strains were slightly reduced in growth at $20 \mathrm{mg} \mathrm{l}^{-1}$ MCFA, while the effect of the $40 \mathrm{mg} \mathrm{l}^{-1}$ MCFA was more pronounced. S. uvarum growth was not influenced considerably by $20 \mathrm{mg} \mathrm{l}^{-1}$ MCFA, while $40 \mathrm{mg} \mathrm{l}^{-1}$ MCFA resulted in noticeable intraspecific variance. E105, SB42, and TKH1 did not seem to be influenced, while S103 decreased moderately and CBS395 showed the highest sensitivity, comparable with that of S. bacillaris (Fig. 2). Z. bailii strains were able to tolerate these concentrations without significant reduction (Fig. 2)
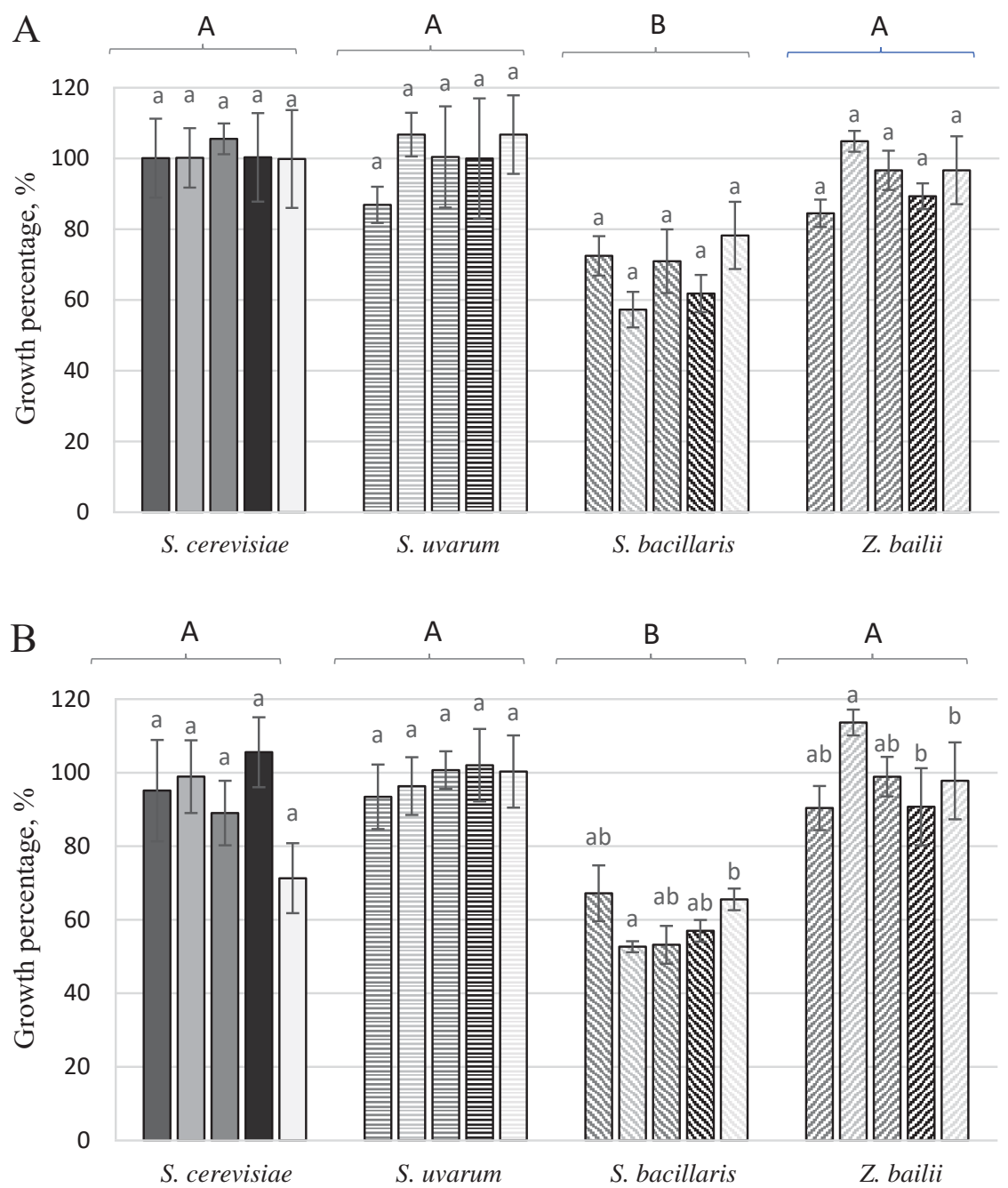

Fig. 2. Growth percentage of the investigated yeast strains: S. cerevisiae ( $\square$ : PM321; : RA100; : S7101;

: Uvaferm $228^{\circledR} ; \quad$ : Uvaferm PM $\left.^{\circledR}\right), S$. uvarum (目: CBS395, Є: E105, 目: S103, 目: SB42, : TKH1),

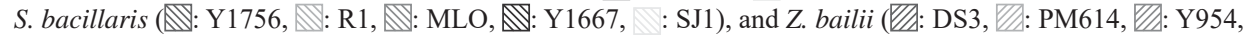
ZA: Z22, : Z6). A: $10 \mathrm{mg} \mathrm{l}^{-1}$ MCFA; B: $20 \mathrm{mg} \mathrm{l}^{-1}$ MCFA; C: $40 \mathrm{mg} \mathrm{l}^{-1}$ MCFA; D: $80 \mathrm{mg} \mathrm{l}^{-1}$ MCFA. Percentage values are calculated from the colony area, normalised by the area of control growth. Columns are means of triplicate drop-tests of each strain. Upon Games-Howell post hoc comparison, means are statistically different at a level $\mathrm{P}<0.05$, indexed with different lower case letter between the strains within each species, with capital letter between species (species means are not displayed) 
$\mathrm{C}$

A

A

B

A

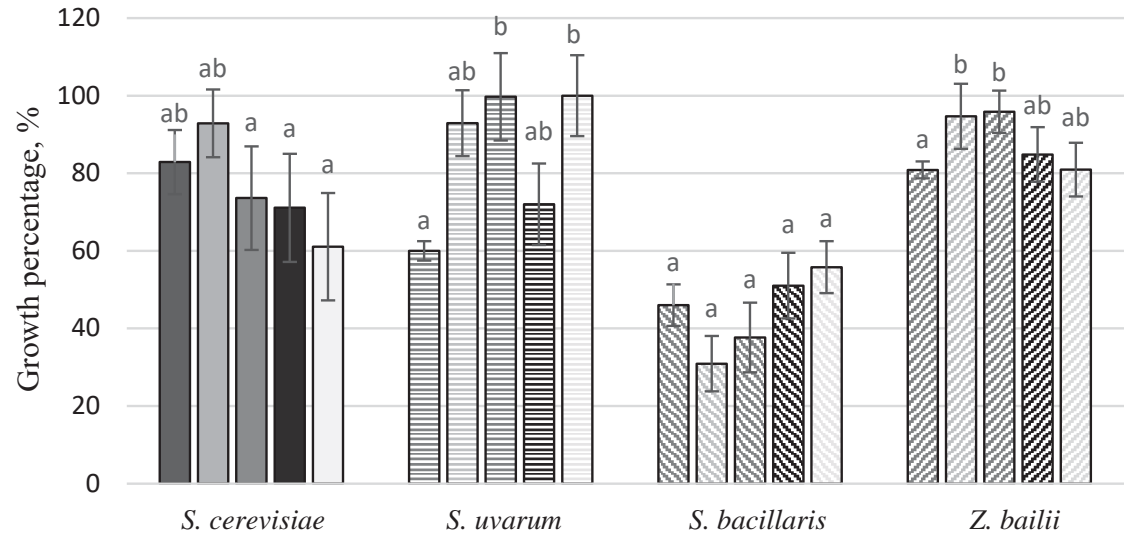

$\mathrm{D}$

A

B

B

C

120

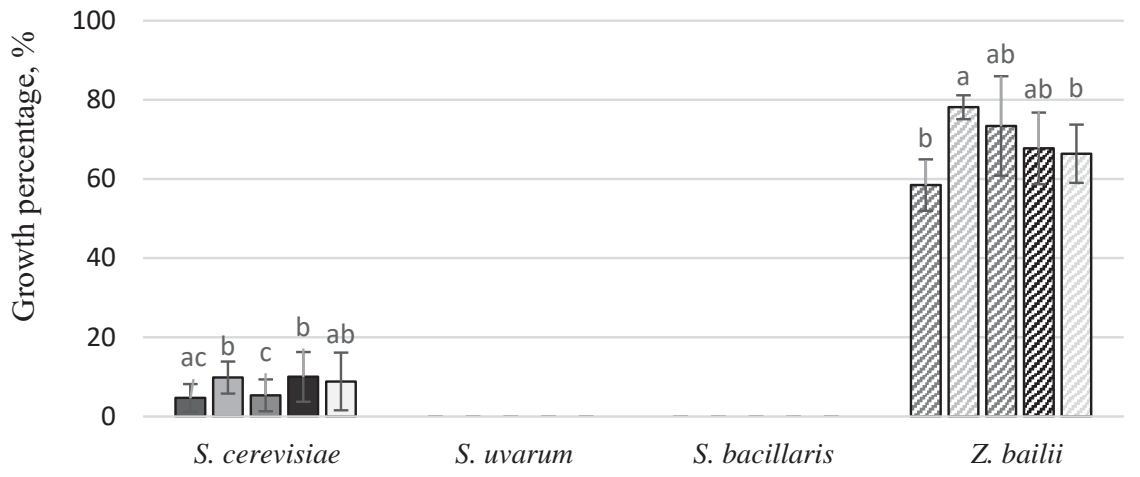

Fig. 2. (continued)

At $80 \mathrm{mg} \mathrm{l}^{-1}$ MCFA, all S. uvarum and S. bacillaris strains were inhibited completely, while some very limited growth was detected in the case of S. cerevisiae strains. Z. bailii strains showed still significant growth and excellent tolerance. This could be a limitation of industrial MCFA application against refermentation, since this wine yeast is often responsible for spoilage of sweet wines (AlONso et al., 2015). In this investigation, MCFA mixture as a sole yeast-inhibitor seemed to be effective only at considerably higher levels than in combinations used in earlier works (BABIKOVA et al., 2012; BARON et al., 2017).

\subsection{Stop of refermentation in Tokaj Essence by MCFA}

At the start, the Tokaj Essence had a considerable yeast concentration of $1.86 \times 10^{5} \mathrm{CFU} \mathrm{ml}^{-1}$, which heterogeneous yeast population presented an excellent overall tolerance towards low 
cellar temperature and extreme amount of sugars (54.19 ${ }^{\circ}$ Brix). In general, MCFA addition had a prompt effect on the population, since after 1 day, the cell concentration decreased by one order of magnitude in the case of 10 and $20 \mathrm{mg}^{-1}$ MCFA, and by two orders of magnitude in the case of $40 \mathrm{mg} \mathrm{l}^{-1} \mathrm{MCFA}$. The $\mathrm{SO}_{2}$ addition in combination with the MCFA did not have additional short-term effect on the yeast population (Fig. 3). Comparing the absolute and sulphited control, it could be seen that this $\mathrm{SO}_{2}$ concentration itself did not inhibit refermentation (Fig. 3), which is in accordance with the high sulphite binding capacity of botrytised wines and general yeast characterisation (Romano \& SuzzI, 1993).

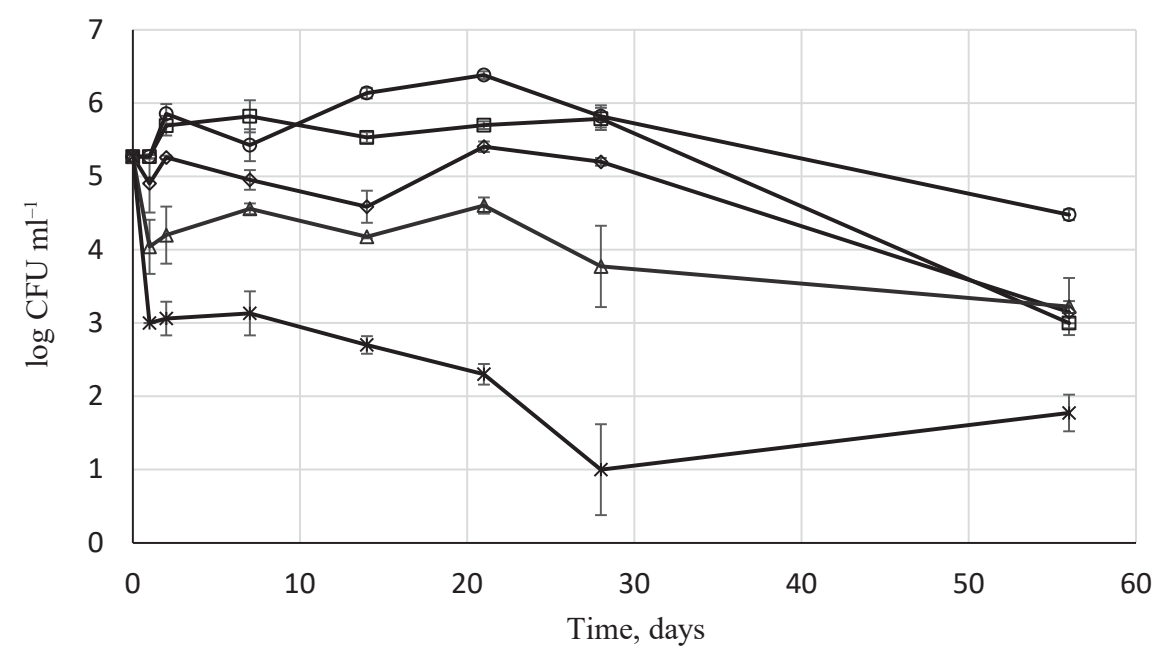

Fig. 3. Yeast population dynamic changes in Tokaj Essence in the presence of various MCFA concentrations in combination with $100 \mathrm{mg} \mathrm{l}^{-1}$ total $\mathrm{SO}_{2}$. Values are means and standard deviations - - - $0 \mathrm{mg} \mathrm{l}^{-1} \mathrm{MCFA}+0 \mathrm{mg} \mathrm{l}^{-1} \mathrm{SO}$; - —: $0 \mathrm{mg} \mathrm{l}^{-1} \mathrm{MCFA}+100 \mathrm{mg} \mathrm{l}^{-1} \mathrm{SO}$; $\checkmark: 10 \mathrm{mg} \mathrm{l}^{-1} \mathrm{MCFA}+100 \mathrm{mg} \mathrm{l}^{-1} \mathrm{SO} 2 ; \_: 20 \mathrm{mg} \mathrm{l}^{-1} \mathrm{MCFA}+100 \mathrm{mg} \mathrm{l}^{-1} \mathrm{SO} 2$; * $: 40 \mathrm{mg} \mathrm{l}^{-1} \mathrm{MCFA}+100 \mathrm{mg} \mathrm{l}^{-1} \mathrm{SO} 2$

The $10 \mathrm{mg} \mathrm{l}^{-1} \mathrm{MCFA}+100 \mathrm{mg}^{-1} \mathrm{SO}_{2}$ had negligible inhibitory effect on the yeast population in the first 28 days, while in the case of $20 \mathrm{mg} \mathrm{l}^{-1} \mathrm{MCFA}+100 \mathrm{mg} \mathrm{l}^{-1} \mathrm{SO}_{2}$ cell concentrations were lower than both controls, but still rather limited inhibition was noticed. The $40 \mathrm{mg} \mathrm{l}^{-1} \mathrm{MCFA}+100 \mathrm{mg} \mathrm{l}^{-1} \mathrm{SO}_{2}$ had more pronounced effect on the refermentation, gradual decline was observed (Fig. 3). After 28 days, the cell concentration decreased to $10^{1}$ CFU ml ${ }^{-1}$ level, but the Essence still cannot be regarded as stable, free from possible refermentation.

After 56 days, the 10 and $20 \mathrm{mg} \mathrm{l}^{-1} \mathrm{MCFA}+100 \mathrm{mg} \mathrm{l}^{-1} \mathrm{SO}_{2}$ reduced the living yeast cell concentration with only two orders of magnitude (Fig. 3), which is a considerable decrease regarding the initial cell number, although the $100 \mathrm{mg} \mathrm{l}^{-1} \mathrm{SO}_{2}$ alone had the same inhibitory effect. In the case of the $40 \mathrm{mg} \mathrm{l}^{-1} \mathrm{MCFA}+100 \mathrm{mg} \mathrm{l}^{-1} \mathrm{SO}_{2}$, the cell concentration remained in the $10^{1} \mathrm{CFU} \mathrm{ml^{-1 }}$ range, however, from an oenological point of view, the lowest remaining cell amount is still not acceptable in bottled wine. These results are difficult to compare with earlier works, since the parameters of the botrytised wine specialties, particularly Tokaj Essence, are considerably different from those in a normal wine. The limited inhibitory effect 
of the MCFA dosage must be influenced by the reduced ethanol content of the Tokaj Essence, which is in accordance with an earlier finding about S. cerevisiae (VIEGAS et al., 1989).

\section{Conclusions}

Due to the increasing MCFA concentrations, considerable differences were detected among the investigated yeast species in growth. S. bacillaris seemed to be the most sensitive, $S$. cerevsisiae and S. bayanus were more tolerant, while $Z$. bailii showed the highest tolerance. It could be concluded that at low ethanol content $(5 \%)$ and without $\mathrm{SO}_{2}$, the MCFA mixture as a sole additive needs to be implied in considerably higher amounts than suggested for normal wines. The inhibitory effect of MCFA should be thoroughly tested in the future with a wider strain set of the currently investigated and other species.

The MCFA- $\mathrm{SO}_{2}$ combinations had rather limited inhibitory effect on the Tokaj Essence refermentation, possibly due to the low alcohol content of the botrytised wine specialty, but the excellent general stress tolerance of the spoilage yeasts should not be excluded. Consequently, the future MCFA application should be reduced only to wine-media, where significant amount of ethanol is present to reach acceptable inhibition.

The authors wish to thank professor Mojmir Baron for his useful suggestions and providing the recipe of MCFA mixture.

\section{References}

Alonso, A., Belda, I., Santos, A., Navascues, E. \& Marquina, D. (2015): Advances in the control of the spoilage caused by Zygosaccharomyces species on sweet wines and concentrated grape musts. Food Control, 51, 129134.

Babikova, P., Baron, M., Kumsta, M. \& Sotolar, R. (2012): Increasing the efficiency of sulfur dioxide in wine by using of saturated higher fatty acids. Acta Univ. Agric. Silvic. Mendel. Brun., 60(1), 17-22.

Balmaseda, A., Bordons, A., Reguant, C. \& Bautista-Gallego, J. (2018): Non-Saccharomyces in wine: Effect upon Oenococcus oeni and malolactic fermentation. Front. Microbiol. 9(534), 1-8.

BAron, M. (2014): Effectiveness of higher fatty acids C8, C10 and C12, dimethyl dicarbonate and sulphur dioxide for inhibition of re-fermentation and malolactic activities in wine. Acta Univ. Agric. Silvic. Mendel. Brun., 62(3), 23-29.

Baron, M., Kumsta, M., Prokes, K., Tomaskova, L. \& Tomkova, M. (2017): The inhibition of Saccharomyces cerevisiae population during alcoholic fermentation of grape must by octanoic, decanoic and dodecanoic acid mixture. BIO Web of Conferences, 9, 02025, Sofia, Bulgaria. Available at https://www.bio-conferences.org/ articles/bioconf/full_html/2017/02/bioconf-oiv2017_02025/bioconf-oiv2017_02025.html (last accessed: 13 May 2020)

EC (2009): Commission Regulation (EC) No 607/2009: Laying down certain detailed rules for the implementation of Council Regulation (EC) No 479/2008 as regards protected designations of origin and geographical indications, traditional terms, labelling and presentation of certain wine sector products. Available at: https:// eur-lex.europa.eu/legal-content/HU/ALL/?uri=CELEX\%3A32009R0607 (last accessed 20 March 2020)

OIV (2018): Compendium of international methods of analysis of wines and musts (2 vol.) Available at: http://www. oiv.int/en/technical-standards-and-documents/methods-of-analysis (last accessed 20 March 2020)

Magyar, I. (2011): Botrytized wines. Adv. Food Nutr. Res., 63, 148-197. 
Magyar, I. \& Tотн, T. (2011): Comparative evaluation of some oenological properties in wine strains of Candida stellata, Candida zemplinina, Saccharomyces uvarum and Saccharomyces cerevisiae. Food Microbiol., 28(1), 94-100.

Masneuf-Pomarede, I., Bely, M., Marullo, P., Lonvaud-Funel, A. \& Dubourdieu, D. (2010): Reassessment of phenotypic traits for Saccharomyces bayanus var. uvarum wine yeast strains. Int. J. Food Microbiol., 139(12), 79-86.

Perez-Torrado, R., Oliveira, B.M., Zemancikova, J., Sychrova, H. \& Querol, A. (2016): Alternative glycerol balance strategies among Saccharomyces species in response to winemaking stress. Front. Microbiol., 7(435), $1-13$.

Romano, P. \& Suzzi, G. (1993): Sulphur dioxide and microorganisms. -in: FleEt, G.H. (Ed.) Wine microbiology and biotechnology. CRC Press, Boca Raton, pp. 373-395.

Santos, M.C., Nunes, C., Saraiva, J.A. \& Coimbra, M.A. (2012): Chemical and physical methodologies for the replacement/reduction of sulfur dioxide use during winemaking: review of their potentialities and limitations. Eur. Food Res. Technol., 234(1), 1-12.

SCHNeIDER, C.A., RASBAND, W.S. \& EliceIrI, K.W. (2012): NIH Image to ImageJ: 25 years of image analysis. Nat. Methods, 9, 671-675.

SIPICZKI, M. (2003): Candida zemplinina sp nov., an osmotolerant and psychrotolerant yeast that ferments sweet botrytized wines. Int. J. Syst. Evol. Micr., 53, 2079-2083.

SIPICZKI, M. (2019): Yeasts in botrytized wine making. -in: Romano, P., Ciani, M., Fleet, G. (Eds) Yeasts in the production of wine. Springer, New York, NY, pp. 229-261.

Viegas, C.A., Rosa, M.F., SACORreia, I. \& Novais, J.M. (1989): Inhibition of yeast growth by octanoic and decanoic acids produced during ethanolic fermentation. Appl. Environ. Microb., 55(1), 21-28.

Zott, K., Claisse, O., Lucas, P., Coulon, J., Lonvaud-Funel, A. \& Masneuf-Pomarede, I. (2010): Characterization of the yeast ecosystem in grape must and wine using real-time PCR. Food Microbiol., 27(5), 559-567.

Open Access statement. This is an open-access article distributed under the terms of the Creative Commons Attribution 4.0 International License (https://creativecommons.org/licenses/by/4.0/), which permits unrestricted use, distribution, and reproduction in any medium, provided the original author and source are credited, a link to the CC License is provided, and changes - if any - are indicated. (SID_1) 